\title{
Channel Choice in the G2B Context: Towards a Research Agenda
}

\author{
Yvon van den Boer, Willem Pieterson, and Rex Arendsen \\ University of Twente, Center for e-Government Studies \\ P.O. Box 217, 7500 AE Enschede, The Netherlands \\ $\{y \cdot$ vandenboer, w. j.pieterson, r.arendsen\}@utwente.nl
}

\begin{abstract}
Knowledge about e-governmental service delivery towards businesses in general and the use and choice of service channels in particular is lacking. Current insights are mostly based on research in the context of citizens. Important differences in both domains can be found in the more networked character of the business context. These differences show that research towards the business context is needed. In order to fill the gap we provide an overview of existing knowledge about channel choice in G2B context. To conclude, we present a research agenda for future research on this topic.
\end{abstract}

Keywords: channel choice, G2B interaction, service delivery, network perspective.

\section{Introduction}

Governmental organizations deliver services to citizens and businesses. Due to higher administrative burdens [1] and the complexity of their relationship with governments, businesses have more contacts with governmental agencies than citizens [1]. Given the importance of e-Services [3] for businesses, the European Commission aims that by $2015,80 \%$ of enterprises will have used e-government. In addition, businesses are expecting high quality in the governmental public service delivery [4]. Therefore, one would expect a large amount of attention in e-government research for the service delivery towards businesses in general, and the use and choice of service channels in particular. However, most of the research in channel choice focuses on citizens [5-7]. Given the complexity of the Government to Business (G2B) relationship, it is questionable whether the findings of Government to Citizens (G2C) studies are fully applicable to the G2B context. This observation calls for insights on channel choice in the G2B context. However, almost no studies exist that examine entrepreneurial channel choice behavior. In order to fill this hole and reach the targets of the European Commission [3], it is important to gain more knowledge about the channel choice behavior of businesses.

The goal of this paper is to review the existing literature on channel choice in the G2B context to provide an overview of the current knowledge and the gaps in the scientific literature. Given the fact that the body of literature in the governmentcitizens context is more developed, we assess the differences between the domains to establish a research agenda for channel choice research in the G2B domain. This leads to the following research questions: 
RQ1 1 What is the current state of the art in theories of channel choice in the G2B context?

$\mathrm{RQ1}_{\mathrm{b}}$ : What is the current state of the art in research of channel choice in the G2B context?

RQ2: How does the existing knowledge about channel choice in the G2B context differ from the knowledge in the G2C context?

RQ3: How do the differences lead to different insights regarding channel strategies?

RQ4: What are the main topics for future research about channel choice in the governmental public service delivery to businesses?

Based on our analysis and the answers to the research questions, we formulate a number of statements that form the basis of the proposed research agenda.

The first section of this paper gives an overview of the backgrounds of channel choice and provides an answer to RQ1 $1_{\mathrm{a}}$. The second section of this paper discusses the existing studies on channel choice of businesses and answers RQ1 $1_{b}$. After that, at the end of the first two sections, an answer will be provided on the second and third research question. The final section discusses possibly interesting topics for upcoming research and will also present a research agenda, which also delivers an answer on RQ4.

\section{Backgrounds of Channel Choice}

In this section we discuss theories of channel choice, focused on both citizens and businesses, in order to answer the first research question (RQ1 $1_{\mathrm{a}}$ ) of this paper.

\subsection{Channel Choice in the G2B Context}

Before we look at channel choice behavior of businesses, we have to provide some definitions of channel choice and apply these to the context of businesses. A channel can be defined as "a customer contact point or a medium through which the firm and the customer interact" [8, p. 96]. In this research, we apply the same definition to G2B interactions. So, the firm in the definition is the governmental agency and the customer is a business. Channel choice is defined as "the choice of the customer to use a specific channel in a specific situation" [9, p. 9]. Again, the customer can be seen as a business in this context. We see channel choice as a bureaucratic confrontation between businesses and governmental agencies [10]. Directing channel choice is defined as "the use of instruments to direct the behavior of citizens in the desired course" [11, p. 10]. In accordance with the other definitions, we can see citizens as businesses in the context of G2B interaction. Subsequently it is important to define a business. Jaffee [12] describes a business as a network of individuals. This network of individuals can be partially influenced and depends on the environment. In addition, a business can be an individual or a group of individuals showing particular behavior [13]. Besides, there is the law of individual differences [14]: 1) Individuals within a business differ in background, experiences, perceptions and expectancies, and 2) individuals react differently to situations. Last of all, we define (communication) networks as: "the patterns of contact that are created by the flow of messages among communicators through time and space" [15, p.3]. 
There are multiple ways to interact with the government. Which channel is chosen depends on the type of service [10]. Table 1 shows that there are different types of channels, and that each type of channel has its own features.

Table 1. Types of channels [10]

\begin{tabular}{lll}
\hline Channel type & Kind of interaction & Example(s) \\
\hline Personal & Face-to-face & Front desk, an intermediary \\
Telephone & Telephonic & \\
Paper & Print media & Mail, fax \\
Electronic & Textual & Websites, e-mail \\
& Audio-visual & Video chat \\
\hline
\end{tabular}

We cannot automatically apply these types of channels into the context of businesses. Hence, we have to make two important remarks about the abovementioned types of channels. The first remark is about the role of the intermediary. Changes in the society itself and changes in technology were leading towards the development of the network society $[16,17]$. According to these changes G2B-relationships were getting increasingly horizontal and were no longer vertical, and information exchange is now fundamental to $\mathrm{G} 2 \mathrm{~B}$ relationships instead of power [18]. These developments changed the role of the intermediaries in the G2B context. Motivated by the use of Internet as a service provision channel new forms of intermediation were necessary [19]. Pieterson [10] presented an intermediary as a personal type of channel in G2C interaction. Others argued, that from a governmental point of view, the intermediary is not a channel but a source of information [1]. An intermediary is more like an external source of information, which can get reached through certain channels. Complexity in the issuing of laws and rules, and sometimes also complexity in technology are supporting arguments for a relationship between a business and an intermediary [12]. Other reasons, especially for small and mediumsized businesses, are an increasing focus on primary products and processes and gaining efficiency benefits [20]. Besides, Pfeffer and Salancik [21] elucidated in their resource dependence perspective that organizations are embedded in an environment with other organizations and are to some extent dependent on resources of others in that environment [21]. They are not completely self-contained. Businesses therefore specialize on their core competences and need others to fulfil secondary tasks. Those others can be seen as the external network of a business. For example, a contractor is specialized in building roads and as any other organization is obliged to fill in the taxes. The primary task of the contractor is building roads and they, usually, have little knowledge how to properly submit their taxes. Therefore, they need another organization that is specialized on accountancy. This firm of accountants is the intermediary party in G2B interaction. From a governmental point of view, the reasons to bring in intermediary organizations are reducing the amount of contact and data collecting points [22]. Intermediaries fulfil different roles in G2B interaction and can be seen as important partners in optimizing (e)governmental services towards businesses [20]. Besides these intermediary organizations (e.g. formal intermediaries), social intermediaries (e.g. friends and family) already fulfil an important role in 
optimizing e-government services towards citizens [23]. However, it is unknown if these social intermediaries also play an important role in the context of businesses. Although, Jansen et al. [1] distinguished different sources and they found that personal network (e.g. external advisors, friends, family, colleagues) can be important for businesses. So, an intermediary is a source of information in the G2B context. This is an important difference in comparison with the context of citizens and adds a networked character to the G2B context.

The second remark is about the rise of social media as the newest form of communication space [24]. Social media can be seen as a potential new channel for egovernmental service [25] and the public sector is slowly adopting this new technology from the private sector [28]. Democratic representatives already use social media to interact with citizens, for example during campaigns [25, 26]. Social media have the potential to leverage a shift towards a more open and collaborative culture [25], as well as filling the gap between politics and citizens [26], increasing accountability [25] and increasing political and societal engagement [25]. Finally, new horizontal communication networks arise from social media and have the typical traits of the network society with regard to technical and organizational structure [24].

Hence, the number of channels and sources used in G2B interactions is higher than taken into account in current G2C studies. Besides, the current state of the art in G2C research does not reflect the actuality of businesses' channel choices. Further, G2B interactions have a far more networked character than G2C interactions, due to the role in all kinds of intermediaries and this networked character impacts their channel behavior.

\subsection{Theories of Channel Choice}

There are different perspectives on channel choice. The first is a rational perspective on channel choice [9]. This perspective is based on the Media Richness Theory [29] and the Social Presence Theory [30]. It assumes that people think in a rational way when they choose a channel. A few years later, the Social Influence Model [31] and the Channel Expansion Theory [32] add a social and subjective side to the model, which implicates that there also are variables that influence channel choice unconsciously. These perspectives have often been criticized because of the lack of empirical support [11].

A recent development in channel choice research, made by Pieterson [10], has resulted in a new theory of channel choice. This theory focuses on citizens in their interaction with the government. Pieterson [10] found that the process of channel choice is not as straightforward as researchers often assumed. When citizens need to choose a channel, they primarily rely on their habits and experiences. In the second instance, there is a rational elaboration. So, citizens use different strategies to make a channel choice when they want to contact the government [10]. Which strategy is chosen depends on personal characteristics (e.g. age or education) as well as task (e.g. complexity of the goal) and channel characteristics (e.g. speed of a channel and its ease of use) [9]. In addition, situational (e.g. a persons need for closure, time and distance) [37] and emotional constraints influence the choice of a strategy.

Before we continue we have to make some remarks here. The abovementioned theory of channel choice [10] focuses on citizens. It is unknown if this theory can 
automatically be placed into the context of businesses. So first of all, research is needed to verify this theory on channel choice of businesses. Secondly, besides the influencing factors on channel choice Pieterson [10] determined, others argued that there are more influencing factors on channel choice. We discuss these factors and point out the most important differences in influencing factors on channel choice of businesses compared to citizens.

First of all, the channel choice of businesses depends on the type of business and thereby on the type of service [9]. It is therefore not unimaginable that characteristics of the organization, such as size, industry and age of the organization have influence on their channel choice behavior. So, besides to the aforementioned influence of personal characteristics [10], the possible influence of organizational characteristics needs to be examined in research on channel choice of businesses in the G2B context.

Secondly, social factors also play an important role in channel choice behavior; because a sympathizer can influence someone else to use a certain channel [33, in 8]. From a social psychology perspective, researchers [34] presume that social norms in a group have influence on the behavior of individuals. This aspect of social influence can bring a new valuable perspective. Keeping in mind that channel choice behavior is an individual action [10], we can imagine that in the business context employees influencing each other's channel choice behavior. In addition, [35, in 12] pointed out some important aspects of organizational reality: 1) structures, like social structural elements (norms, hierarchy etc.) 2) processes that are goal directed and 3) outcomes, the consequences of both structures and processes on employees, the organization itself and the whole society. The first aspect is important for channel choice behavior because the social structural elements have influence on behavior of the individual within the organization and it shows the difference between a citizen and an employee [36]. So in this case, the group can be seen as a network of individuals that together form a business. We call this the internal network of a business. Here we can identify the distinction between the individual as a citizen and the individual as part of the internal network of a business. Compared to channel choice of citizens, individuals get influenced in their channel choice by their colleagues within the internal network, which is the business. This is the third statement we make, which adds a network perspective to channel choice of businesses and shows the importance of gaining more specific knowledge about channel choice of businesses.

In order to answer the first research question (RQ1 $1_{\mathrm{a}}$ ) concerning the current state of the art of theories in channel choice of businesses, we draw these conclusions: First of all, there is little knowledge of theories in channel choice behavior of businesses in a governmental public service delivery context. Moreover, we only found a channel choice theory of Pieterson [10] concerning the channel choice behavior of citizens in a governmental service delivery context. Nevertheless, we cannot apply this theory straight into the business context, because the influence of the factors on channel choice is unknown in a business context. All in all, we found three important differences between the context of citizens and the context of businesses, which lead towards the following statements:

St1 There are more channels and sources to take into account in G2B interaction compared to the current knowledge of channel choice in G2C interaction. 
St2 The context of G2B interaction seems to have a more complex and networked character than the context of $\mathrm{G} 2 \mathrm{C}$ interaction, because of the presence of intermediaries.

St3 The channel choice of an employee is influenced by the social norms within the internal network of a business, which gives the channel choice of businesses in a governmental service delivery context an even more networked character.

These differences lead towards the overall statement that the theory about channel choice of citizens cannot directly be applied to the business context. So, further research is needed to identify all the factors of influence regarding channel choice behavior of businesses. In the next section we will find out if we can gain more information about the factors influencing channel choice of businesses.

\section{Research of Channel Choice in the G2B Context}

In this section we review the few studies that have been conducted on businesses' channel choice (Table 2). In this section we discuss these findings to provide an answer on RQ1 $1_{b}, R Q 2$ and RQ3.

Table 2. Overview of existing studies of channel choice behavior of businesses

\begin{tabular}{lll}
\hline Subject & Authors & N \\
\hline Channel preference and/or use & De Vos [39] & 115 \\
& Van den Boom [40] & 601 \\
& Jansen \& Pieterson [36] & 323 \\
& Van de Wijngaert et al. [4] & 323 \\
Motivations to use a channel & De Vos [39] & 115 \\
& Van den Boom [40] & 601 \\
& Van de Wijngaert et al. [4] & 323 \\
Perceptions of channels & De Vos [39] & 115 \\
Functions of channels & Van de Wijngaert et al. [4] & 323 \\
Source choice & Jansen et al. [1] & 323 \\
\hline
\end{tabular}

In this analysis, we focus on five key aspects of businesses' channel behavior; 1) general use and channel preference, 2) the reasons businesses have to choose a certain channel, 3) their perceptions of service channels, 4) the functions of channels and finally, 5) the selection of a certain information source.

First and foremost, researchers found that channel preference does not automatically lead to the use of that preferred channel [39, 36, 4]. So, intentions are not always determined for behavior [36]. More specifically, the most preferred channel of businesses in a governmental context is the telephone, closely followed by the Internet [39,36]. However, Van den Boom [40] found that email is preferred above the website. Here, the telephone is one of the least used channels. On the other hand, the channel most used by businesses is the telephone with the Internet in second place $[39,36,4]$. So, there seems to be a switch between the telephone and Internet regarding preference and use of channels (Table 3 ). 
Table 3. Channel preference versus Channel use

\begin{tabular}{|c|c|c|c|c|}
\hline Authors & Most preferred channel & $\%$ & Most used channel & $\%$ \\
\hline \multirow[t]{2}{*}{ De Vos [39] } & 1. Telephone & 42 & 1. Internet & 49 \\
\hline & 2. Internet & 41 & 2. Telephone & 39 \\
\hline \multirow[t]{2}{*}{ Jansen \& Pieterson [36] } & 1. Telephone & 65 & 1. Internet & 53 \\
\hline & 2. Internet & 21 & 2. Telephone & 30 \\
\hline
\end{tabular}

The second point concerns the motivations to use a channel. The most important motivations in general are ease and speed [39]. For the phone, the design plays a role. The motivations to choose the desk are design and certainty. In addition to this, others found that other motivations to choose a certain channel are goal and situation [40,4]. We have to remark that these findings are based on questions about intentional behavior and are not based on actual behavior. As we saw before in this paper, intention and behavior are not always the same [13].

There also is some knowledge about the perceptions of channels, from a business point of view. Businesses perceive the telephone as an appropriate channel for clarifying situations, using different languages, having a quick answer, reaching their goal and to obtain the best service and experience [39]. Businesses also perceive the Internet as a cheap channel, appropriate for the searching of information. However, when we compare the perceptions of channels from businesses [39] and citizens [9], we see a difference in perceptions of channels (figure 2.). Channel perceptions vary largely between the different groups, leading to different possibilities for service delivery.

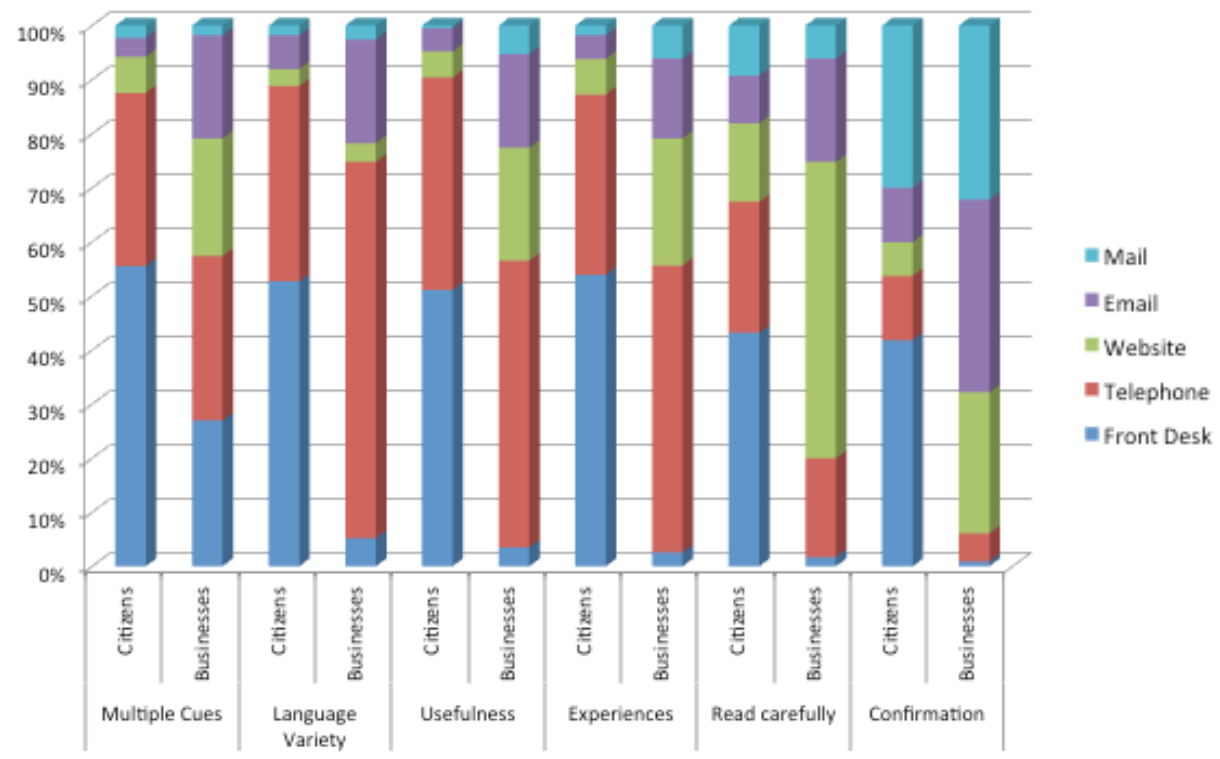

Fig. 2. Channel perceptions: citizens [9] versus businesses [39] 
An explanation for the different perceptions can be found in the difference of the tasks in both contexts because of different service delivery [36]. Another important explanation can be derived from the more networked character at business level of G2B interaction, as we discussed in the theory section, compared to G2C interaction. More specifically, the presence of the internal network of businesses can lead towards different perceptions of channels by an individual as part of a business instead of being a citizen. For example, the individual as a citizen would go to the front desk for an answer on a specific question. In contrast, the individual as part of a business would use the telephone to get an answer on that question because all colleagues are doing the same and it is not common to go to the desk. In this case, the telephone is perceived as more useful in the business context instead of the front desk in the citizens' context. So, this leads to the statement that the channel perception of an employee is influenced by the social norm within the internal network (e.g. colleagues) of the business.

Regarding the fourth point, there is little knowledge about the functions businesses attribute to the channels Internet, telephone and desk. Businesses use the Internet as a channel when they have a general and simple question [4]. When questions get more specific and are more important for the businesses, they mostly use the telephone or the desk as a channel to interact with the government.

Besides, research shows that citizens sometimes use different channels to reach a specific goal [38]. For example, a citizen first looks for more information on a website, and afterwards he or she verifies the information at a service desk with faceto-face communication. Furthermore, others found that businesses also use different channels when they contact the government [4].

Finally, Jansen et al. [1] researched the source choice of businesses in a public service context. They distinguished between sources in ones personal network (e.g. external advisors, family and friends, internal and external colleagues), expert organizations (e.g. chamber of commerce, professional organizations), government organizations (e.g. national government and municipalities), portals and search engines. They found that compared to smaller businesses, larger businesses make less use of expert organizations and more use of their personal network. Finally, they also found that importance of the issue and the needed specificity of the information are important factors for source choice.

To conclude this section, we formulate an answer on the first research question (RQ1b): What is the current state of the art in research of channel choice in the G2B context? Presently, there are a few studies that researched the channel choice of businesses in the governmental public service delivery context. There is very little knowledge about the factors that influence channel choice of businesses. Moreover, most studies examined the measurable outcomes of channel choice, like channel preference and use, and provided some possible explanations of their findings. So, the current studies are just an exploration of channel choice of businesses and thorough research is needed. However, one remarkable finding is worth to mention here: the intention to use a certain channel, does not automatically lead to the use of that preferred channel $[39,36,4]$. 
The second research question (RQ2) was: How does the existing knowledge about channel choice in the G2B context differ from the knowledge in the G2C context? We found two important differences between channel choice of businesses and citizens that leads to the following statements:

St4 Businesses and citizens have different perceptions of channels. An explanation can be derived from the theory discussed in the first section. Compared to citizens, individuals as employees are influenced in their channel choice by an internal network (e.g. colleagues) of a business. There is a difference in context.

St5 Source of information seems to be a more important factor in the understanding of channel choice of businesses compared to citizens. The reason for this can be found in the more networked character of the business context compared to the context of citizens. In this case, we mean the external network of the business in their interaction with the government during service delivery.

With this in mind, we can formulate an answer on the third research question (RQ3): How do the differences lead to different insights regarding channel strategies? So far, our study illustrates that the context of channel choice in governmental public service delivery to businesses is different from that to citizens, as the various statements make clear. So, the development of a multichannel strategy in channel choice for G2B interaction seems to be highly desirable. In this way, businesses will choose the right channel for the right service. However, the current theory and research about channel choice of businesses is very scarce. In the next section of this paper we will provide a research agenda on this topic in order to extend the knowledge of channel choice of businesses in the near future.

\section{Conclusion: A Research Agenda}

The goal of this paper is to review the existing literature on channel choice in the G2B context in order to provide an overview of the current knowledge and the gaps in the scientific literature. Our study shows that theories in the $\mathrm{G} 2 \mathrm{C}$ context cannot directly be applied to the G2B context, because of crucial differences between both domains. Besides, the few studies conducted on G2B interaction are merely an exploration and thorough research is needed. In this section we give an overview of the statements and present research topics for future research in G2B interaction, which answers RQ4.

The first topic on the research agenda focuses on the number of channels and sources used in G2B interaction. The following statement was presented:

St1 There are more channels and sources to take into account in G2B interaction compared to the current knowledge of channel choice in $\mathrm{G} 2 \mathrm{C}$ interaction.

First, keeping in mind that intermediaries can be seen as sources of information instead of a channel in G2B interaction, it is desirable to gain more insight regarding different kinds of sources in order to determine their influence on channel choice of businesses. Secondly, there is little knowledge about social media as potential new 
channel in G2B service delivery. Hence, it is essential to extend the understanding on: 1) the potential role of social media in G2B interaction during service delivery and 2) the current role of social media in other forms of interaction with the environment of businesses. In order to estimate the potential role of social media in the G2B context it is desirable to focus on the characteristics of social media in terms of richness (e.g. task/media fit) for example [29]. Besides, perceived characteristics (e.g. relative advantage, compatibility) of social media could give more understanding about this topic [42].

The second topic on the research agenda considers the influence of the external network of businesses on their choice behavior. The following statement was formulated:

St2 The context of G2B interaction seems to have a more complex and networked character than the context of $\mathrm{G} 2 \mathrm{C}$ interaction, because of the presence of intermediaries

As we discussed before, it is preferable to bring in intermediary organizations, from both business and governmental perspectives. Source choice is a key factor here. From the governmental perspective it will be desirable to identify important players in the network in order to become aware of the influence of intermediaries on the channel choice of businesses. However, there is little insight regarding the interaction between intermediaries and businesses and how it is influencing channel choice of businesses. In order to fill this research gap it is essential to gain knowledge about the external network of businesses and determine the influencing factors from the environment on the channel choice of businesses. Hence, a relevant perspective for future studies regarding channel choice behavior in the G2B context is to consider the interaction between businesses, intermediaries and governments as a social network. The (social) network analysis method can provide insight in the influence of relations between businesses and intermediaries on channel choice behavior in G2B interaction during service delivery [43]. Factors like structural equivalence, proximity, symmetry and trust are meaningful aspects in understanding and describing a network and the influences of relations on business behavior [15].

The third topic of this future research agenda considers the internal network of businesses. We presented the following statement:

St3 The channel choice of an employee is influenced by the social norms within the internal network of a business, which gives the channel choice of businesses in a governmental service delivery context an even more networked character.

The current literature provides little insight into the influencing factors on channel choice of employees. It is unknown to what extent business channel choice behavior is caused by individuals on the one hand, and the business itself on the other hand. For example, do employees have high autonomy to make their own choices, or are there rules for choosing a channel to contact the government? In other words, what are the influencing factors on the realization of business channel choice behavior? Relevant factors here seem to be social influence (e.g. direct statements, vicarious learning, norms for media behavior) and situational factors (e.g. individual 
differences, facilitating factors, constraints) [31], in order to determine perceived influence of colleagues and supervisors on channel choice of an employee.

Concerning the abovementioned topics for future research the social influence model of Fulk et al. [31] seems to be the most relevant theory for explaining channel choice of businesses. Furthermore, the theory of channel choice of citizens by Pieterson [10] could bring in some significant influencing factors regarding channel choice of businesses. However, it is not the case that existing theories provides us a complete view of the formation of today's business' channel choice behavior. Hence, personal characteristics (e.g. age, education) [10] and characteristics of businesses (e.g. size, industry and type of business) [2] should be taken into account when businesses choose their channel in order to contact the government. Especially the presented network perspective can be of added value in order to understand channel choice of businesses. Monge and Contractor [15] made a strong argument for multilevel theories of communication networks, which seems applicable to the G2B context, due to the possibility of linking several levels of networks. This network perspective can give more insight in the influence relationships with colleagues (internal network, organizational level) and other organizations (external network, interorganizational level) have on channel choice behavior of businesses in the context of G2B interaction. Thus, characteristics of the internal as well as the external network of businesses should be topics of interest.

Regarding the fourth research question (What are the main topics for future research about channel choice in the governmental public service delivery to businesses?) we can distinguish three main research topics: 1) the number of channels and sources to take into account in G2B interaction, 2) the role of the external network, with the presence of intermediaries, on the realization of business channel choice and 3) the role of the internal network in the realization of business channel choice. In order to examine these topics of future research the first step would be to explore the determinants of business' channel choice. The next phase would be to empirically validate these antecedents in order to conceptualize a model that explains channel choice behavior of businesses.

To summarize, the networked character of the business context indicates to be the factor that makes it a complex field, but it also seems to be the key towards understanding channel choice behavior of businesses. Therefore, the network perspective is of great added value in order to understand and predict channel choice behavior of businesses. Moreover, with regard to the ambitions of the European Commission [3] it is even of greater value to extend the knowledge on channel choice behavior in order to optimize (e-)governmental service delivery to businesses.

\section{$5 \quad$ Implications}

Besides the presented research agenda, we can already provide some implications for governments in order to take the first step towards the understanding of business channel choice. First, the implication for governments is that the current channel strategies of citizens are not suitable to the context of businesses. Besides, it is essential to pay attention to the role of the intermediaries as a source in government-business interaction. In particular, a distinction between social and 
formal intermediaries possibly delivers a better understanding of different influences on choice behavior of businesses. Finally, the role of networks related to the intermediaries, are crucial in understanding business choice behavior. For these reasons, a multichannel strategy in channel choice of businesses in governmental service delivery is highly desirable.

\section{References}

1. Arendsen, R., Van Engers, T.V., TeVelde, R.: An Empirical Study on Business-toGovernment Data Exchange Strategies to Reduce the Administrative Costs for Businesses. In: Suomi, R., et al. (eds.) Project E-Society: Building Bricks, 6th IFIP Conference on eCommerce, e-Business and e-Government, vol. 226, pp. 311-323. Springer, Boston (2006)

2. Jansen, J., Van de Wijngaert, L., Pieterson, W.: Channel Choice and Source Choice of Entrepreneurs in a Public Organizational Context: The Dutch Case. In: Wimmer, M.A., Chappelet, J.-L., Janssen, M., Scholl, H.J. (eds.) EGOV 2010. LNCS, vol. 6228, pp. 144 155. Springer, Heidelberg (2010)

3. European Commission: The European eGovernment Action Plan 2011-2015: Harnessing ICT to promote smart, sustainable \& innovative Government. European Commission, Brussels (2010)

4. van de Wijngaert, L., Pieterson, W., Jansen, J., van Dijk, J.: Kanaalkeuze en bronkeuze van ondernemers in de publieke context en de rol van Antwoord $\odot$ voor bedrijven daarin. Universiteit Twente, Enschede (2010)

5. Pieterson, W., Ebbers, W.: The use of service channels by citizens in the Netherlands: Implications for multi-channel management. International Review of Administrative Sciences 74, 95-110 (2008)

6. Reddick, C.G.: Citizens interactions with e-government: From the streets to servers? Government Information Quarterly 22, 38-57 (2005)

7. Thomas, J.C., Streib, G.: The new face of government: Citizens-initiated contacts in the era of e-government. Journal of Public Administration Research and Theory 13(1), 83-102 (2003)

8. Neslin, S.A., Grewal, D., Leghorn, R., Shankar, V., Teerling, M.L., Thomas, J.S., Verhoef, P.C.: Challenges and opportunities in multichannel customer management. Journal of Services Research 9(2), 95-112 (2006)

9. Pieterson, W., Teerling, M.L.: Kanaalkeuze: klanten kiezenkanalen. Novay, Enschede (2008)

10. Pieterson, W.: Channel choice: Citizens' channel behavior and public service channel strategy. Gildeprint B.V., Enschede (2009)

11. Teerling, M.L., de Vos, H., van de Wijngaert, L., Boekhoudt, P., Ebbers, W.: Kanaalsturing: Ten gunste van het digitale kanaal. Novay, Enschede (2009)

12. Jaffee, D.: Organization Theory: Tension and change. McGraw-Hill, New York (2001)

13. Jansen, J., Pieterson, W.: Dienstverlening aan bedrijven: Een conceptueel gedragsbeïnvloedingmodel. Universiteit Twente, Enschede (2010)

14. Davis, K.: Human behavior at work: Organizational behavior. McGraw-Hill, New York (1981)

15. Monge, P.R., Contractor, N.S.: Theories of Communication Networks. University Press, Oxford (2003)

16. van Dijk, J.A.G.M.: The Network Society: Social aspects of New Media. Sage, London (2006) 
17. Castells, M.: The New Public Sphere: Global Civil Society, Communication Networks, and Global Governance. The ANNALS of the American Academy of Political and Social Science 616(1), 78-93 (2008)

18. Castells, M.: The rise of the network society. Blackwell Publishing, Cornwall (2000)

19. Janssen, M., Klievink, B.: Improving Governmental Service Delivery: Disintermediation and Re-intermediation strategies for Multi-channel management. In: Proceedings of the 8th European Conference on e-Government, pp. 319-326. Academic Publishing Limited, Reading (2008)

20. Arendsen, R., ter Hedde, M.J.: On the Origin of Intermediary e-Government Services. In: Wimmer, M.A., Scholl, H.J., Janssen, M., Traunmüller, R. (eds.) EGOV 2009. LNCS, vol. 5693, pp. 270-281. Springer, Heidelberg (2009)

21. Pfeffer, J., Salancik, G.R.: The external control of organizations: A resource dependence perspective. Harper \& Row, New York (2003)

22. Allers, M.A.: Administrative and Compliance Costs of Taxation and Public Transfers in the Netherlands, dissertation. Rijksuniversiteit Groningen, Groningen (1994)

23. Millard, J.: E-governance and E-participation: Lessons in promoting inclusion and empowerment. In: E-Participation and E-Government: Understanding the Present and Creating the Future (2006)

24. Castells, M.: Communication, Power and Counter-power in the Networks Society. International Journal of Communication 1, 238-266 (2007)

25. Moreira, A.M., Möller, M., Gerhardt, G., Ladner, A.: E-Society and E-Democracy. Paper presented at the eGovernment-Symposium 2009, Berne, Switzerland (2009)

26. Vergeer, M., Hermans, L.: Campaigning on Twitter: Twitter as a campaign tool in the general elections 2010 in the Netherlands. Paper presented at the Etmaal van de Communicatiewetenschap 2011, Enschede, The Netherlands (2011)

27. Breindl, Y.: Critique of the Democratic Potentialities of the Internet: A Review of Current Theory and Practice. TripleC 8(1), 43-59 (2010)

28. Mergel, I.A., Schweik, C.M., Fountain, J.E.: The Transformational Effect of Web 2.0 Technologies on Government (June 1, 2009), Available at SSRN: http: / /ssrn. com/abstract=1412796 (2009)

29. Daft, R.L., Lengel, R.H.: Information richness: A new approach to managerial behavior and organizational design. In: Cummings, L.L., Staw, B.M. (eds.) Research in Organizational Behavior, vol. 6, pp. 191-233. JAI Press, Homewood (1984)

30. Short, J., Williams, E., Christie, B.: The social psychology of telecommunications. John Wiley, London (1976)

31. Fulk, J., Schmitz, J., Steinfeld, C.W.: A social influence model of technology use. In: Fulk, J., Steinfeld, C.W. (eds.) Organizations and Communication Technology. Sage Pubications, London (1990)

32. Carlson, J.R., Zmud, R.W.: Channel expansion theory and end the experiental nature of media richness perceptions. The Acadamy of Management Journal 42(2), 153-170 (1994)

33. Verhoef, P.C., Neslin, S.A., Vroomen, B.: Browsing versus buying: Determinants of customer search and buy decisions in a multi-channel environment (working paper). Rijkuniversiteit Groningen, Groningen (2005)

34. Postmes, T., Steg, L., Keizer, K.: Groepsnormen en gedrag: Sturing door sociale identiteit en dialoog. In: Tiemeijer, W.L., Thomas, C.A., Prast, H.M. (eds.) De Menselijke Beslisser. Amsterdam University Press, Amsterdam (2009)

35. Hall, R.: Organizations: Structures, processes, and outcomes. Prentice Hall, Englewood Cliffs (1999) 
36. Jansen, J., Pieterson, W.: State of the art voor het kanaalkeuzegedrag van bedrijven. Universiteit Twente, Enschede (2010)

37. Nicholson, M., Clarke, I., Blakemore, M.: One brand, three ways to shop: Situational variables and multichannel consumer behavior. The International Review of Retail, Distribution and Consumer Research 12(2), 131-148 (2002)

38. Ebbers, W., Pieterson, W., Noordman, H.: Electronic government: Rethinking channel management strategies. Government Information Quarterly 25(2), 181-201 (2008)

39. de Vos, H.: Kanaalkeuze: Voorkeuren van ondernemers. Novay, Enschede (2008)

40. van den Boom, J.G.G.V.: Ondernemers gaan voor e-overheid: Wat verwacht de ondernemer van de dienstverlening van de overhead?. Ernst \& Young, Den Haag (2009)

41. Arendsen, R.: Geen bericht, goed bericht: Een onderzoek naar de effecten van de introductie van elektronisch berichtenverkeer met de overheid op de administratieve lasten van bedrijven. Amsterdam University Press, Amsterdam (2008)

42. Rogers, E.M.: Diffusion of innovations, 5th edn. The Free Press, New York (2003)

43. Wasserman, S., Faust, K.: Social Network Analysis: Methods and Applications. Cambridge University Press, Cambridge (1994) 